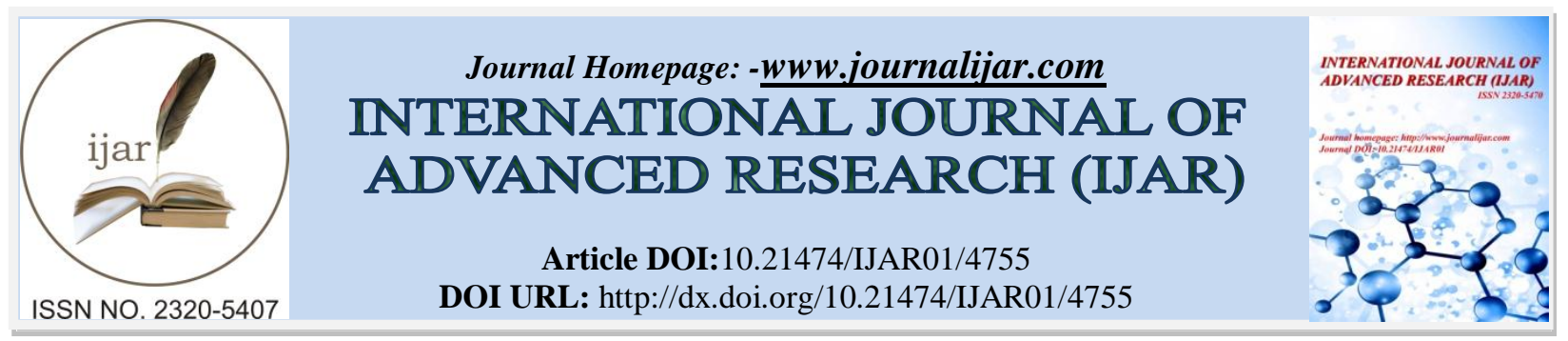

RESEARCH ARTICLE

\title{
STUDY ON THE PRODUCTION AND ANTIBACTERIAL ACTIVITIES OF BIOSURFACTANT PRODUCED FROM SOME BACTERIAL SPECIES.
}

\author{
${ }^{*}$ Chioma Okore ${ }^{1}$, Linda Nwaehiri ${ }^{1}$, Ogechukwu Mbanefo ${ }^{1}$, Toochukwu Ogbulie ${ }^{2}$, Assumpta Ugenyi ${ }^{2}$,Ifeanyi \\ Ogbuka $^{1}$,Agunna Ejele ${ }^{3}$ and Ikechukwu Okwujiako ${ }^{2}$. \\ 1. Environmental Biology Dept, Federal Polytechnic NekedeOwerri, Imo-State. \\ 2. Biotechnology Dept, Federal University of Technology Owerri, Imo-State. \\ 3. Chemistry Dept, Federal University of Technology Owerri, Imo-State.
}

\section{Manuscript Info}

Manuscript History

Received: 5 May 2017

Final Accepted: 7 June 2017

Published: July 2017

Key words:-

Biosurfactant production, antimicrobial activity, Staphylococcus aureus, Bacillus sp., Pseudomonas aeruginosa, Proteus sp., Corynebacterium sp.

\begin{abstract}
Biosurfactant are produced by some micro organisms. Kerosene was used as substrate to enhance the production of biosurfactant by Staphylococcus aureus, Bacillus sp., Pseudomonas aeruginosa, Proteus sp. and Corynebacteriumsp. Staphylococcus aureus produced the highest 0.5 g, Bacillus sp., Pseudomonas aeruginosa and Proteus sp. $0.2 \mathrm{~g}$, Corynebacterium sp. the least $0.1 \mathrm{~g}$. The biosurfactant demonstrated antibacterial activity against the test bacteria (Staphylococcus sp. and Pseudomonas aeruginosa). The biosurfactant produced by Pseudomonas aeruginosa gave the highest zone of inhibition against Staphylococcus aureus, Bacillus sp., Corynebacteriumsp., $(25 \mathrm{~mm})$. The biosurfactant produced by Staphylococcus aureus gave the highest zone of inhibition against Pseudomonas aeruginosa $(39 \mathrm{~mm})$, Corynebacteriumsp., and Proteus sp. $(30 \mathrm{~mm})$, Bacillus sp. the least zone $(25 \mathrm{~mm})$. The production of biosurfactantand antibacterial efficacy can thus be promising for use in medical, therapeutics, pharmaceuticals, cosmetcs, food and beverages for treatment and control of diseases caused by micro organisms.
\end{abstract}

Copy Right, IJAR, 2017,. All rights reserved.

\section{Introduction:-}

Biosurfactants are amphiphilic compounds that contain a hydrophobic portion and a hydrophilic group. They are produced by yeast or bacteria growing on various substrates e.g., sugars, oils, alkanes and wastes (Jinfenget al., 2005). Biosurfactants are grouped as glycolipids (e.g., rhamnolipids, trehalolipids, sophorolipids), lipopeptides (e.g., surfactin, iturin, lichenysin), phospholipids, fatty acids and neutral lipids (e.g., Corynomycolic acid, Spiculisporic acid, Phosphati-dylethanolamine), polymeric and particulate compounds (e.g., Emulsan, Alasan, Biodispersan, Liposan, Mannoprotein) (Calvoet al., 2009). Most of these compounds are either anionic or neutral. Only a few are cationic such as those containing amine groups. The hydrophobic part of the molecules is based on long-chain fatty acids, hydroxyl fatty acids or $\alpha$-alkyl- $\alpha$-hydroxy fatty acids. The hydrophilic portion can be a carbohydrate, amino acid, cyclic peptide, phosphate, carboxylic acid or alcohol. The various types are produced by different organisms, rhamnolipids (Pseudomonas spp.), trehalolipids (Rhodococcus erythropolis, Arthrobacter sp., Nocardia sp., Corynebacterium spp.), sophorolipids (Candida spp., Torulopsis spp.); surfactin, iturin, lichenysin (Bacillus spp.); Corynomycolic acid (Corynebacterium lepus); Spiculisporic acid (Penicillium spiculisporum); Phosphati- 
dylethanolamine (Acinetobacter spp., Rhodococcus erythropolis); Emulsan (Acinetobacter calcoaceticus RAG-1); Alasan (Acinetobacter radioresistens KA-53); Biodispersan (Acinetobacter calcoaceticusA2); Liposan (Candida lipolytica); Mannoprotein (Saccharomyces cerevisiae) (Pacwa-Plociniczaket al., 2011). Pseudomonas aeruginosa can produce rhamnolipids from substrates including $\mathrm{C}_{11}$ and $\mathrm{C}_{12}$ alkanes, succinates, pyruvate, citrate, fructose, glycerol, olive oil, glucose and mannitol (Sifour et al., 2007). The composition and yields depend on the fermentor design, $\mathrm{pH}$, nutrient composition, substrate and temperature used (Joseph and Joseph, 2009). Biosurfactants can be potentially as effective with some distinct advantages over the highly used synthetic/chemical surfactants. Biosurfactants have high specificity, biodegradability, biocompatibility and less toxicity e.g., glycolipids from Rhodococccus species 413A were 50\% less toxic than Tween 80 in naphthalene solubilization tests (Christofi and Ivshina, 2002). Among the genus Bacillus spp., Bacillus subtilis produces a broad spectrum of bioactive lipopeptides which have a great potential for biotechnological and biopharmaceutical applications. The characteristic structure of lipopeptides is a fatty acid combined with an amino-acid moiety. Several lipopeptides have potent antibiotic activity and have been the subject of several studies on the discovery of new antibiotics. The surfactin, produced by $B$. subtilis, is the most powerful of biosurfactant known to date. These compounds have many pharmacological activities: antibacterial, antifungal, antiviral, and antimycoplasma properties; inhibition of the fibrin clot formation and hemolysis; formation of ion channels in lipid bilayer membranes (Gudinaet al., 2010); antitumour activity against Ehrlich's ascites carcinoma cells; and inhibition of the cyclic adenosine 3,5monophosphate phosphodiesterase (Fernandes et al., 2007). Lipopeptides have a broad spectrum of action, including antimicrobial activity against microorganisms with multidrug-resistant profiles (Gudina et al., 2010). Some biosurfactants are able, even in low concentrations, to destabilize the microorganism's membranes, killing them or disabling their growth (Calvo et al., 2009; Carrilo et al., 2003).

The microbially produced surfactants are alternatives to chemical surfactants whose effects have been reported variously by authorities. The effects of surfactants on the human body are divided into effects on the skin and in the body. The main ingredients of modern life detergents are surfactants, long-term use cause skin irritation effect and lead to some degree of damage. After the surfactants enter into the human body, they damage the enzyme activity and thus disrupt the body's normal physiological function. Surfactants have some toxicity and may accumulate in the human body, so it is difficult to degrade (Venhuis and Mehrva, 2004). In general, nonionic surfactants are not electrically charged, not combined with protein. They have minimal irritation to the skin. The toxicity of cationic surfactants is the biggest, and the toxicity of anionic surfactants is between that of non-ionic surfactants and cationic surfactants. Prolonged exposure of skin to surfactants can cause chafing because surfactants (e.g. soap) disrupt the liquid coating that protects skin and other cells. There have been the reports that SDBS (sodium dodecyl benzene sulfonate) is absorbed through the skin, they damage the liver and cause narrowing and other chronic symptoms, as well as teratogenic and carcinogenic (Toll et al., 2000). It is based on these effects that this study was carried out to determine the biosurfactant producing ability of Staphylococcus aureus, Pseudomonas aeruginosa, Bacillus sp., Corynebacteriumsp., Proteus sp. and ascertain their antimicrobial prorperties for applications in medical, therapeutics, pharmaceuticals, cosmetcs, food and beverages for treatment and control of diseases caused by micro organisms.

\section{Materials and methods:-}

The materials used included peptone water, stock cultures of Staphylococcus aureus, Bacillus sp., Corynebacterium sp., Pseudomonas aeruginosa, and Proteus sp., $0.2 \mathrm{M} \mathrm{H}_{2} \mathrm{SO}_{4}$, chloroform, methanol, centrifuge, glass Petri-dish, Pasteur pipette, measuring scale, $\mathrm{pH}$ meter.

\section{Production of biosurfactant:-}

Biosurfactant was produced using stock cultures of Staphylococcus aureus, Bacillus sp., Corynebacterium sp, Pseudomonas aeruginosa, and Proteus sp. A loopful of each of the isolates was placed in $5 \mathrm{ml}$ of sterile peptone water in a test tube and $0.1 \mathrm{ml}$ of hydrocarbon (kerosene) was added to enhance the growth of the bacterial species. The suspensions were then allowed to stand for $48 \mathrm{~h}$. After the $48 \mathrm{~h}$ incubation at room temperature, the biosurfactant produced by each microorganism was extracted as described by Anandaraj and Thivakaran, (2010); Okore et al., (2017a; 2017b).

\section{Extraction of biosurfactant:-}

The biosurfactant produced by each of the isolates was extracted by centrifuging at $5000 \mathrm{rpm}$ for 20 min to obtain a cell-free supernatant of each of the test organisms. Then $1 \mathrm{ml}$ supernatant of each of the suspension was taken and placed in a sterile glass Petri-dish and acidified with $1 \mathrm{ml}$ of $2 \mathrm{M} \mathrm{H}_{2} \mathrm{SO}_{4}$ to obtain a pH of 2.0. Thereafter, the 
biosurfactant produced was extracted using a mixture of chloroform and methanol in the ratio of 1:2 (1 ml of chloroform: $0.5 \mathrm{ml}$ of methanol). The mixture of biosurfactant and the extracting solvents (chloroform and methanol) was allowed for $24 \mathrm{~h}$ to evaporate at room temperature. Then the biomass of biosurfactant produced was determined by subtracting the total weight of the Petri-dish with the biosurfactant from the initial weight before the experiment (Okore et al., 2017a; 2017b).

\section{Antibacterial activity of the biosurfactant produced:-}

The disc technique as described by Osadebe and Ukwueze, (2004) was adopted for this study to evaluate the antibacterial activity of the biosurfactants. About $0.2 \mathrm{ml}$ aliquot of the biosurfactants were dropped on sterile filter paper disc of about $6 \mathrm{~mm}$ in diameter and allowed to get absorbed before they were placed into nutrient agar plates inoculated with each of the test organisms Staphylococcus aureus and Pseudomoas aeruginosa and appropriately labelled, discs impregnated with water and ethanol were used as control in each case. The plates were then incubated at $37^{\circ} \mathrm{C}$ for $24 \mathrm{~h}$ and the zones of inhibition obtained by each of the biosurfactant were measured.

\section{Results:-}

The results of the production of biosurfactant by the stock culture of Staphylococcus aureus, Bacillus sp., Corynebacterium sp., Pseudomonas aeruginosa, and Proteus sp. are presented in Table 1 and result for the antimicrobial activities of the biosurfactant produced on Table 2 and Table 3.

Table 1:-Weight of biosurfactant (grams) produced by the bacterial isolates.

\begin{tabular}{|l|l|l|l|}
\hline Bacteria & $\begin{array}{l}\text { Weight of Petri dish } \\
\text { before extraction }(\mathrm{g})\end{array}$ & $\begin{array}{l}\text { Weight of Petri dish } \\
\text { after extraction }(\mathrm{g})\end{array}$ & $\begin{array}{l}\text { Weight of biosurfactant } \\
(\mathrm{g})\end{array}$ \\
\hline Staphylocococcus aureus & 40.2 & 40.7 & 0.5 \\
\hline Bacillus sp. & 38.3 & 38.5 & 0.2 \\
\hline Corynebacterium sp. & 50.7 & 50.8 & 0.1 \\
\hline Pseudomonas sp. & 51.5 & 51.7 & 0.2 \\
\hline Proteus sp. & 50.0 & 50.2 & 0.2 \\
\hline
\end{tabular}

Table 2:-Zones of inhibition of the biosurfactant produced by Staphylococcus aureus on test organisms.

\begin{tabular}{|l|l|l|l|l|}
\hline Test organisms & N2 & N4 & N22 & N7 \\
\hline $\begin{array}{l}\text { Zones of inhibition (mm) of biosurfactant by } \\
\text { Staphylococcus aureus }\end{array}$ & 25 & 30 & 30 & 39 \\
\hline $\begin{array}{l}\text { Zones of inhibition (mm) using ethanol } \\
\text { (control) }\end{array}$ & - & - & - & - \\
\hline Zones of inhibition (mm) using water (control) & - & - & - & - \\
\hline
\end{tabular}

Table 3:- Zones of inhibition of the biosurfactant produced by Pseudomonas sp.on test organisms

\begin{tabular}{|l|l|l|l|l|}
\hline Test organisms N2 & N2 & N22 & N1 \\
\hline $\begin{array}{l}\text { Zones of inhibition (mm) of biosurfactant by } \\
\text { Pseudomonas sp. }\end{array}$ & 25 & 25 & 18 & 25 \\
\hline $\begin{array}{l}\text { Zones of inhibition (mm) using ethanol } \\
\text { control) }\end{array}$ & - & - & - & - \\
\hline $\begin{array}{l}\text { Zones of inhibition (mm) using water } \\
\text { (control) }\end{array}$ & - & - & - & - \\
\hline
\end{tabular}

Key: N1 = Staphylococcus aureus

$\mathrm{N} 2$ = Bacillus $\mathrm{sp}$., N4 = Corynebacterium $\mathrm{sp}$.

N7 = Pseudomonas aeruginosa

$\mathrm{N} 22=$ Proteus $\mathrm{sp}$.

$(-)=$ No zone of inhibition

\section{Discussion:-}

The results of the mass of biosurfactant produced by the different bacterial species as presented in Table 1 indicated that Staphylococcus arueus produced the highest quantity of biosurfactant $(0.5 \mathrm{~g})$ while Corynebacterium sp. the 
least (0.1 g); Bacillus sp., Pseudomonas sp. and Proteus sp. produced $0.2 \mathrm{~g}$ of biosurfactant each. Anandaraj and Thivakaran (2010) equally obtained a dry weight of $0.122 \mathrm{~g}$ of biosurfactant from Pseudomonas sp. This study has confirmed that some bacterial spp. produce biosurfactant when grown on kerosene as have been documented by many authorities. Santa Anna et al., (2002) investigated the production of biosurfactant from Pseudomonas aeruginosa PA1 isolated from oil wells grown on N-Hexadecane. Several studies (Santa et al., 2001; Priya and Usharani, 2009; Liu et al., 2011; Dhail and Jasuja, 2012; Okore et al., 2013; Tambekar and Gadaki, 2013; Hassanshahia, 2014) also identified biosurfactant production by Pseudomonas spp. Bacillus spp. have equally been reported to produce biosurfactant by these studies (Ahimonu et al., 2001; Joshi et al., 2008; Okore et al., 2013; 2017a; 2017b; Chakarabarti, 2015). Corynebacterium spp. have been identified as by works of Muthusamy et al., (2008); Franzetti et al., (2010); Sai-Ard et al., (2013), to produce biosurfactant.

The Staphylococcus aureus and Proteus sp. grown on kerosene as the carbon source yielded $0.5 \mathrm{~g}$ and $0.2 \mathrm{~g}$ of biosurfactant. These two organisms have scarcely been reported in literature as biosurfactant producers, as emphases have been on the use of non pathogenic strains for biosurfactant production with specificity to the area of application.

The above Table 2 and 3, show the variation in the zones of inhibition by each of the biosurfactants produced from the bacterial species. The biosurfactant produced from Pseudomonas aeruginosa had the highest zones of inhibition against Staphylococcus aureus, Bacillus sp., Corynebacterium sp. (25 mm) and least on Proteus sp. (25 mm). The biosurfactant produced from Staphylococcus aureus gave the highest zone of inhibition against Pseudomonas aeruginosa $(39 \mathrm{~mm})$, followed by Corynebacterium sp. $(30 \mathrm{~mm})$ and Proteus $\mathrm{sp} .(30 \mathrm{~mm})$, the Bacillus sp. gave the least $(25 \mathrm{~mm})$. The control (water and ethanol) did not show any zones of inhibition against the test organisms. Many researchers have demonstrated the antimicrobial activity of different Pseudomonas spp. Govindammal and Parthasarathi (2013), studied the antimicrobial property of Pseudomonas flurescens MFSO3 on Bacillus subtilis and Staphylococcus aureus. The recorded zones of inhibition ranging from $15 \pm 0.5 \mathrm{~mm}$ to $21 \pm 0.14 \mathrm{~mm}$ for Bacillus subtilis; $17 \pm 0.14 \mathrm{~mm}$ to $23 \pm 0.26 \mathrm{~mm}$ for Staphylococcus aureus; $14 \pm 0.16 \mathrm{~mm}$ to $18 \pm 0.23 \mathrm{~mm}$ for Methicillinresistant Staphylococcus aureus (MRSA). Khare and Arora (2011), worked with fluorescent Pseudomonas against Macrophomnina phaseolina ARIFCC257 a plant pathogenic fungus and recorded zones of inhibitions of $42 \mathrm{~mm}$ and $36 \mathrm{~mm}$. Abalos et al. (2002), investigated the inhibitory activity of biosurfactant from Pseudomonas aeruginosa ATIO. They recorded zones of inhibitions on Escherichia coli, Micrococcus luteus, Alcaligenes faecalis, Serratia marcescens, Mycobacterium phlei and Staphylococcus epidermidis. The antimicrobial activity of surfactin was tested against several microbes. All tested bacteria, except for Bacillus. subtilis, showed susceptibility to surfactin. $P$. aeruginosa was the most sensitive Gram-negative bacteria, while E. coli, Salmonella choterasius and Serratia marcescens were inhibited in a lower level. Also, the lipopeptide affected the growth of Gram-positive bacteria, especially Micrococcus luteus and Bacillus cereus (Rodrigues et al., 2006a; 2006b; 2006c). These biosurfactants can be used in the production of antibiotics that are specific to the target bacteria since the biosurfactants produced will likely be specific to certain genes or genomic composition of the target bacteria.

\section{Conclusion and recommendation:-}

Biosurfactant can be produced from bacterial broth cultures supplemented with hydrocarbons (e.g. kerosene) and extracted by acidification followed by liquid liquid extraction with chloroform-methanol mixture in the ratio of 2:1. The biosurfactants also have pronounced antibacterial activities against Staphylococcus aureus and Pseudomonas aeruginosa. The Staphylococcus aureus is well implicated in causing various infections including wound infections and other superficial infections. This thus validates the reported medical importance of biosurfactant. It is therefore recommended that biosurfactant be massively produced as well as purified and used in the production of pharmaceutical products due to their proven antimicrobial activities.

\section{Reference:-}

1. Abalos, A., Pinazo, A., Infante, M. R., Casals, M., Garcia, F., and Manresa, A., (2001). Physicochemical and antimicrobial properties of new rhamnolipids produced by Pseudomonas aeruginosa AT10 from soybean oil refinery wastes. Langmuir. 17(5):1367-1371.

2. Ahimou, F., Jacques, P., and Deleu, M., (2001). Surfactin and iturin A effects on Bacillus subtilis surface hydrophobicity. Enzyme and Microbial Technology. 1(27):749-754.

3. Anandaraj, B., and Thivakaran, P., (2010). Isolation and production of biosurfactant producing organisms from oil spilled soil. Biosci Tech. 1(3):120-126. 
4. Calvo, C., Manzanera, M., Silva-Castro, G.A., Uad,I., and Gonzalez-Lopez, J., (2009). Application of biomemulsifiers in soil oil bioremediation processes. Future prospects. Sci. Total Environ. 407:3634-3640.

5. Carrilo, C., Teruel, J.A., Aranda, F.J. and Ortiz, A. (2003) . Molecular mechanism of membrane permeabilization by the peptide antibiotic surfactin. Biochimica et Biophysica Acta. 1611: 91-97.

6. Chakrabarti, S., (2015). Bacterial biosurfactant: Characterization, antimicrobial and metal remediation properties. Dissertation submitted in partial fulfillment of the requirement for the degree of Master of Science in life science. Department of life science national institute of technology Rourkela Odisha. pp. 1-62

7. Christofi, N., and Ivshina, I., (2002). Microbial surfactants and their use. In soil remediation book: Bioremediation of aquatic and terrestrial ecosystems. pp. 311-327.

8. Dhail, S., and Jasuja, N., (2012). Isolation of biosurfactant-producing marine bacteria. African Journal of Environmental Science and Technology. 6(6):263-266. DOI: 10.5897/AJEST12.068.

9. Fernandes, A., Arruda, I.R., Santos, A.F.A.B., Araújo, A., Maior, A.M., and Ximenes, E.A., (2007). Antimicrobial activity of surfactants produced by Bacillus subtilis R14 against multidrug resistant bacteria. Brazilian Journal of Microbiology. 38:704-709.

10. Franzetti, A., Gandolfi, I., Bestetti, G., Smyth, T.J., and Banat, I.M., (2010). Production and applications of trehalose lipid biosurfactants. Eur. J. Lipid. Sci. Tech. 112:617-627.

11. Govindammal, M., and Parthasarathi, R., (2013). Investigation on antimicrobial activity of biosurfactant produced by Pseudomonas fluorescens isolated from the mangrove ecosystem. International Research Journal of Pharmacy. 4(1):230-232 http://www.iriponline.com

12. Gudiña, E.J., Rocha, V., Teixeira, J.A., and Rodrigues, L.R., (2010). Antimicrobial and antiadhesive properties of a biosurfactant isolated from Lactobacillus paracasei SSP. Paracasei A20. Applied Microbiology. 50:419424.

13. Hassanshahian, M., (2014). Isolation and characterization of biosurfactant producing bacteria from Persian Gulf (Bushehr provenance). Marine Pollution Bulletin 86:361-366.

14. Jinfeng, L., Lijun, M., Bozhong, M., Rulin, L., Fangtian, N., and Jiaxi, Z., (2005). The field pilot of microbial enhanced oil recovery in a high temperature petroleum reservoir. J. Petrol. Sci. Eng.48:265-271.

15. Joseph, P.J., and Joseph, A., (2009). Microbial enhanced separation of oil from a petroleum refinery sludge. $J$. Hazard. Mater. 161:522-525.

16. Joshi, S., Bharucha, C., and Desai, A.J., (2008b). Production of biosurfactant and antifungal compound by fermented food isolate B. subtilis 20B. Biores. Technol. 99:4603-4608.

17. Khare, E., and Arora, N., (2011). Physiochemical and structural characterization of biosurfactant from fluorescent Pseudomonas with biocontrol activity against Macrophomina phaseolina In: Proceedings of the $2^{\text {nd }}$ Asian PGPR conference August 21-24 2011, Beijing P.R. China.

18. Liu, T., Hou, J., Zuo, Y., Bi, S., and Jing J., (2011). Isolation and characterization of a biosurfactant producing bacterium from Daqing oil-contaminated sites. African Journal of Microbiology Research. 5(21):3509-3514. DOI: 10.5897/AJMR11.684.

19. Muthusamy, K., Gopalakrishnan, S., Ravi, T.K., and Sivachidambaram, P., (2008). Biosurfactants: Properties, commercial production and application. Current Science. 94:736-774.

20. Okore, C. C., Nwaehiri, L. U., Mbanefo, O.N., Ogbulie, T. E., Ugenyi, A. U., Ogbuka, I. B., Ejele A. E. and Okwujiako I. A. (2017a). Study on effect of monovalent and divalent salts on the production of biosurfactant and emulsification index. Int. J. Adv. Res. 5(6) : 1875-1881, Doi:10.21474/IJAR01/4616, ISSN: 2320-5407

21. Okore, C. C., Nwaehiri, L. U., Mbanefo, O.N., Ogbulie, T. E., Ugenyi, A. U., Ogbuka, I. B., Ejele A. E. and Okwujiako I. A. (2017b). Study on microbial diversity of biosurfactant producing bacteria from contaminated enviromental samples. Int. J. Adv. Res. 5(6): 1387-1396, Doi:10.21474/IJAR01/4548, ISSN: 2320-5407.

22. Okore, C.C., Mbanefo, O.N., Onyekwere, B.C., Onyewenjo, S., Abba-Father, C.A.M. (2013). Isolation and Characterization of Biosurfactants Producing Bacteria from Oil Polluted Soil",Journal of Natural Sciences Research www.iiste.org. ISSN 2224-3186 (Paper) ISSN 2225-0921 (Online). 3(5) pp 119-122

23. Osadebe, P.O. and Ukwueze, S.E. (2004). A comparative study of the phytochemical and antimicrobial properties of the eastern Nigerian species of African mistletoe (Loranthus micranthus) sourced from different host trees. Journal of Biological Research and Biotechnology, 2:18 -23

24. Płociniczak, M.P., Płaza, G.A., Seget, Z.P., and Cameotra, S.S., (2011). Environmental Applications of Biosurfactants: Recent Advances. Int. J. Mol. Sci., 12:633-654. Doi 10.3390/ijms 12010633.

25. Priya, T., and Usharani, G., (2009). Comparative study for biosurfactant production by using Bacillus subtilis and Pseudomonas aeruginosa. Botany Research International. 2(4):284-287 ISSN 2221-3635.

26. Rodrigues, L.R, Moldes, A, Teixeira JA, Oliveira R. (2006a). Kinetic study of fermentative biosurfactant production by Lactobacillus strains. Biochemical Engineering Journal. 28:109-116. 
27. Rodrigues, L.R, Teixeira, J.A, Van Der Mei H.C., Oliveira R., (2006b). Isolation and partial characterization of a biosurfactant produced by Streptococcus thermophilusA. Colloids and Surfaces B: Biointerfaces. 53:105 -112.

28. Rodrigues, L.R., Banat, I.M., Van der Mei, H.C., Teixeira, J.A., and Oliveira, R., (2006c). Interference in adhesion of bacteria and yeasts isolated from explanted voice prostheses to silicone rubber by rhamnolipidbiosurfactants. Journal of Applied Microbiology. 100(3):470-480.

29. Saisa-Ard, K., Maneerat, S., and Saimmai, A., (2013). Isolation and characterization of biosurfactantsproducing bacteria isolated from palm oil industry and evaluation for biosurfactants production using low-cost substrates. BioTechnologia. Journal of Biotechnology, Computational Biology and Bionanotechnology. 94(3):275-284.

30. Santa Anna, M., Sebastian, G.V., Menezes, E.P., Alves, T.L.M., Santos, A.S, Pereira Jr., N., and Freire, D.M.G., (2002). Production of biosurfactants from Pseudomonas aeruginosa PA1 isolated in oil environments. Brazilian Journal of Chemical Engineering. 19:(2): 159-166.

31. Santa Anna, I.M., Sebastian, G.V., Pereira, J.R.N., Alves, T.L.M., Menezes, E.P., and Freire, D.M.G., (2001). Production of biosurfactant from a new and promising strain of Pseudomonas aeruginosa PA1. Appl. Biochem. Biotechnol. 91:459-67. http://dx.doi.org/10.1385/ABAB:91-93:1-9:459.

32. Sifour, M., Al-Jilawi, M.H., and Aziz, G.M., (2007). Emulsification properties of biosurfactant produced from Pseudomonas aeruginosa RB28. Pak. J. Biol. Sci. 10:1331-1335.

33. Tambekar, D.H., and Gadakh, P.V., (2013). Biochemical and molecular detection of biosurfactant producing bacteria from soil. Int. J. Life Sc. Biotechnology and Pharma. Research. 2(1):204-211.

34. Tolls, J., Haller, M., Seinen, W., Sijm, D.T., and LAS. H.M., (2000). Bioconcentration: Tissue distribution and effect of hardness implications for processes. Environ. Sci. Technol. 34:304-10.

35. Venhuis, S. H., and Mehrva, M., (2004). Health effects, environmental impacts, and photochemical degradation of selected surfactants in water. International Journal of Photoenergy. 2:115-125. 